\begin{tabular}{|c|c|c|}
\hline $\begin{array}{l}\text { ÇÜTAD } \\
\text { Çukurova Üniversitesi } \\
\text { Türkoloji Araștırmaları Dergisi }\end{array}$ & & $\begin{array}{l}\text { Cilt 6, Sayı } 2 \\
\text { Aralı } 2021\end{array}$ \\
\hline $\begin{array}{l}\text { ISSN: 2587-1900 } \\
\text { E-ISSN: 2548-0979 }\end{array}$ & $\begin{array}{l}\text { Geliş Tarihi: } \\
\text { Kabul Tarihi: }\end{array}$ & $\begin{array}{l}10.01 .2021 \\
: 16.06 .2021\end{array}$ \\
\hline \multicolumn{3}{|c|}{$\begin{array}{l}\text { Makale Künyesi (Araştırma): Doğaner, A. (2021). Aslantaş Barajı'nın } \\
\text { Çukurova halk kültürüne etkisi. Çukurova Üniversitesi Türkoloj } \\
\text { Araştırmaları Dergisi, } 6(2), 515-545 \text {. }\end{array}$} \\
\hline \multicolumn{3}{|c|}{ https://doi.org/10.32321/cutad.857773 } \\
\hline
\end{tabular}

\title{
ASLANTAŞ BARAJI'NIN ÇUKUROVA HALK KÜLTÜRÜNE ETKİSI
}

\begin{abstract}
Ali DOĞANER ${ }^{1}$
ÖZET

Baraj, su üzerine engel konularak engel gerisinde kalan geniș bir havzada suyun toplanması ve tutulması şeklinde oluşturulan yapıdır. Suyun toplanmasıyla; tarım alanlarını sulama, taşkınları önleme, enerji üretme, içme suyu temin etme gibi birçok amaca hizmet eden barajların 5000 yıllık bir geçmişe sahip olduğu bilinmektedir. Merkezî yönetimler tarafından insanlığa hizmet amacıyla inşa edilen barajlar, özellikle de kurulduğu bölgelerdeki insanları çeşitli yönlerden etkilemektedir. Araştırmamızın merkezini oluşturan Aslantaş Barajı'nın yaklaşık on yıl süren yapımı sırasında ve 1983 yılında hizmete girmesi sonrasında yöre insanlarında oluşturduğu etkiler, olumlu ve daha çok da olumsuz yönleriyle halk şiirinde dile getirilmiştir. $\mathrm{Bu}$ etkiler tarlaların sular altında kalması sonucunda geçim sıkıntılarının başlaması, evlerin kaybedilmesiyle farklı yerleşim yerlerine göçlerin yaşanması, insanların âdeta kök saldıkları topraklardan koparılmasıyla maddi ve manevi sıkıntılara düşmesi şekillerinde olumsuz; elektrik üretimi, su kaynaklarının verimli kullanılması, çiftlik balıkçılığına elverişli olması, hoş bir manzara oluşturması, turizmi canlandırması gibi olumlu şekillerde örneklendirilebilir.
\end{abstract}

Anahtar kelimeler: Çukurova, Aslantaş Barajı, halk şiiri, göç.

\section{THE EFFECT OF ASLANTAŞ DAM ON ÇUKUROVA FOLK CULTURE}

\begin{abstract}
The dam is a structure created by placing an obstacle on the water to collect and hold back the water in a wide basin behind the obstacle. Serving many purposes with the collection of water such as irrigation of agricultural lands, preventing floods, generating energy
\end{abstract}

${ }^{1}$ Osmaniye Korkut Ata Üniversitesi, Fen-Edebiyat Fakültesi, Türk Dili ve Edebiyatı Bölümü, Dr. Öğr. Üyesi. adoganer80@hotmail.com https://orcid.org/0000-0003-4600-8350 
and providing drinking water, it is known that dams have a 5000-year history. Dams built by central governments to serve humanity affect people in various ways, especially those in the regions where they are established. The effects of Aslantaş Dam, constituting the center of our study, on local people during its ten-year lasting construction and after its completion in 1983 were expressed in folk poetry with its positive and more negative aspects. The effects can be exemplified negatively, such as the beginning of livelihood difficulties as a result of flooding of the fields, the migration to the different settlements with the loss of homes, and the material and moral problems arisen from the loss of people's homes; and positively, such as the electricity generation, the efficient use of water resources, the suitability for farm fishing, creating pleasant landscape, and stimulating tourism.

Keywords: Çukurova, Aslantaş Dam, folk poetry, migration.

\section{GíRiş}

Su, yaşamın kaynağıdır. İnsanlarla birlikte tüm canlılar, hayatını sürdürebilmek için suya ihtiyaç duymaktadır. İnsanlar yetiştirdikleri tarım ürünleri, besledikleri hayvanlar için de su gereksinimi duymuş ve bunu karşılayabilmek için su kaynaklarına yakın olmaya çalışmışlardır. Bunun yanı sıra kuyu açarak, su kanalları yaparak çeşitli malzemelerden ürettikleri borular vasitasıyla ya da kaplarla ellerinde, omuzlarında ya da hayvan sırtlarında taşıma yoluyla su temin edebilmişlerdir.

Suyun sürekli temin edilebilmesi için depolanmasına da ihtiyaç duyulmuştur. $\mathrm{Bu}$ amaçla çeşitli araç gereçler üretilmiş, yapılar oluşturulmuştur. Bunlardan biri de akarsular üzerine set oluşturarak yapılan barajlardır. Anık'a göre; barajlar en az 5.000 yıldan beri içme ve sulama suyu temin ederek sayısız eski uygarlıkların ilerlemesine katkıda bulunan yapılardır (Anık, 1997, s. 31). Bunun yanında inşaat mühendisliğinin en çok dikkati çeken, muhteşem ve kompleks yapıları olan barajların; çevreye, doğal hayata ve insan yaşamına olumlu ya da olumsuz etkileri söz konusu olabilmektedir (Anık, 1997, s. 28). Çağlar'a göre; bulgular, genel olarak baraj projesinin yararlarının zararlarından çok daha fazla olduğunu göstermektedir (Çağlar, 2002, s. 47).

Maddi kültür unsuru olarak değerlendirilebilecek barajlar; halkın kendisinin yapmadığı, yapılmasına karar vermediği fakat yapımında işçi olarak çalıştığı, yapıldıktan sonra istihdam oluşturduğu, çevredeki yerleşim yerlerinin etkilendiği bir yapı özelliği taşımaktadır.

Barajların inşasında enerji elde etme, sulama, taşkınları önleme gibi amaçların gözetildiği bilinmektedir. Bunların yanında baraj 
inşaatından sonra mesire alanlarının oluşması, balıkçılık yapılması, turizm geliri elde etme gibi sonuçlar da görülmektedir. Genel anlamda barajlar, olumlu sonuçlar elde etmek amaciyla inşa edilmektedir. Ancak, barajlar inşası sırasında ve sonrasında barajdan etkilenen halkın tarım arazilerini kaybetmesi, zorunlu ya da gönüllü göçe tabi tutulmaları ve bunların beraberinde getirdiği sosyo-ekonomik sıkıntılar, hastalıklar, bunalımlar gibi olumsuz sonuçlara da neden olabilmektedir.

Anık, barajların insanlar üzerindeki olumsuz etkilerini şu cümlelerle açıklamaktadır:

"Asırlardan beri bulundukları yaşam ortamlarından insanların koparılıp başka yerlere yerleştirilmeleri barajların en büyük çevre sorunudur. Bu insanlar, başkalarına fayda temini için zorla göçe tabi tutulmanın verdiği psikolojik ezikliğin etkisi altındadırlar." (Anık, 1997, s. 33).

Anık, baraj yapımından etkilenen insanlar için yapılması gerekenleri şöyle sıralamaktadır:

"Proje çevre bedeli olarak yüklenmek üzere, bu insanların yaşam seviyesini yükseltecek şekilde her türlü altyapı tesisleri ile donatılmış yeni yerleşim birimlerine yerleştirilmeleri baraj sahibinin en önde gelen görevi olmalıdır. Ayrıca, bu insanların genellikle eski uğraş konuları olan tarım alanında çalışmaları için modern tarım yapma imkânlarına kavuşturulmaları da yeni yerleşim biriminin ayrılmaz bir parçasını teşkil etmelidir. Yeniden yerleşime tabi tutulmak istemeyenlerin mülkleri için ödenecek bedel de bu insanların yakın çevrede yeni konut almaya ve iş tutmaya yetecek seviyede olmalıdır." (Anık, 1997, s. 33).

Anık'ın önerilerinin barajdan etkilenen insanların daha çok maddi ihtiyaçlarını karşılamaya yönelik olduğu, bu önerilerde sosyopsikolojik gereksinimlere ise doğrudan değinilmediği görülmektedir.

Türkiye'de Osmanlı döneminden kalma barajlar da bulunmaktadır. Baraj yapımı, kontrolü ve kullanımı uzun yıllar DSİ'nin sorumluluğunda sürdürülmüştür. 1993 yılında Türkiye Elektrik Anonim Şirketi (TEAŞ) kurularak DSI'nin bazı sorumlulukları bu kuruluşa devredilmiştir (Öner, 2001, s. 16).

Türkiye'de ilk barajlar sulama, taşkın önleme, içme ve kullanma suyu için yapılmıştır. Elektrik enerjisi üretilebilecek barajların yapımına 1956 yılından sonra Ankara ili sınırları içinde, Sakarya Irmağı üzerinde kurulan Sarıyar Barajı ile başlanmıştır. Aynı yıl Adana'da Seyhan Barajı işletmeye açılmıştır (Yeni Resimli Bilgi Ansiklopedisi, 1983, s. 2235). 
Bu çalışmada Aslantaş Barajı'yla ilgili literatür taraması yapılmış ve ardından gerçekleştirilen alan araştırmasında görüşme ve gözlem teknikleri kullanılmıştır. Elde edilen veriler iki başlık altında örnekler verilerek incelenmiştir.

\section{ASLANTAŞ BARAJI VE KÜLTÜREL ETKILERİ}

Aslantaş Barajı'nın; üzerine kurulu olduğu Ceyhan Nehri, doğduğu yer olan Elbistan ilçesi sınırlarından, denize döküldüğü Akdeniz Deltası'na kadar 509 km'lik uzunluğa sahiptir. DSİ'nin ilgili biriminden alınan verilere göre Aslantaş Barajı'nın yapımına yönelik kamulaştırma çalışmaları 1973 yılında başlamış ve 1983 yılında tamamlanmıştır (Çağlar, 2002, s. 59). Ceyhan Nehri üzerine inşa edilen ilk baraj olan Aslantaş Barajı'ndan sonra aynı nehir üzerine Berke, Sır, Menzelet, Kılavuzlu gibi barajlar da inşa edilmiştir.

Aslantaş Barajı'yla birlikte toprakları sular altında kalacak olan yöre insanı, memnuniyetsizliğini dile getirmiş olsa da projede bölge ve ülke ekonomisine katkı gözetilmiştir. Bununla birlikte projede "nehir boyundaki köyleri taşkınlardan kurtarma ve sulama" (Çağlar, 2002, s. 49) gibi bölgesel faydalar da amaçlanmıştır.

Aslantaş Barajı'nın kurulduğu bölgede Türkiye'nin sayılı millî parklarından biri bulunmaktadır. Aslantaş Barajı'na da adını veren bu yer Karatepe Aslantaş Millî Parkı ve Açık Hava Müzesi'dir. Prof. Halet Çambel tarafindan gün yüzüne çıkarılan bu bölge, yine Çambel'in katkılarıyla baraj altında kalmaktan kurtarılmıştır. "Çambel'in yoğun çabaları sonunda, baraj ilk tasarlanan gövde yüksekliğinden $12,5 \mathrm{~m}$ daha aşağıya çekilmiş ve böylece müze sular altında kalmaktan kurtulmuştur.” (Çağlar, 2002, s. 84).

Aslantaş Barajı'nın yapılması bölgedeki bazı tarihî yapıları olumsuz yönde etkilemiştir. Roma dönemine ait olan Kum Kalesi, Aslantaş Barajı altında kalmıştır (K.2, K.5, K.10).

Aslantaş Barajı'nın açılışına gelen zamanın başbakanı Süleyman Demirel'in Adana Milletvekili Selahattin Kılıç'a "Bu kadar araziyi sular altında bırakacağınıza, biraz daha yukardan tutsaydınız ya suyu. Yazık etmişsiniz bunca toprağa ve köylüye.” (K.1, K.3, K.4) ya da "Bu barajın bu kadar alanı kapladığını, bu kadar toprağın su altında kalacağını bilsem barajı yaptırmazdım." (K.5) şeklinde serzenişte bulunduğu yörede hâlen anlatılmaktadır.

Aslantaş Barajı'nın yapımından olumlu ya da olumsuz etkilenebilecek hiçbir kesimle devlet yetkilileri görüşmemiş, onları bilgilendirmemiştir. Yerlerinden edilen veya yeniden yerleştirilen köylüler, karşılaşacakları olası durumlar, yeni yaşamları ve 
alternatifler konusunda bilgilendirilmemiş, bilgi ve isteklerine başvurulmamış, planlama ve yeniden yerleştirilme sürecine katılmamış ve yeni yaşamlarına hazırlama gibi bir eğitim vb. yapılmamıştır (Çağlar, 2002, s. 56).

Aslantaş Barajı, 1996 yılına kadar sadece Adana ve Kahramanmaraş'ın Ceyhan Nehri kıyısında yer alan yerleşim yerlerini ilgilendirmekte iken 1996 yılında Osmaniye'nin Adana'dan ayrılıp il olmasıyla etki alanına Osmaniye de dâhil olmuştur. Barajın etki alanını şu şekilde sınıflandırmak mümkündür:

1. Baraj Gölü'nün yer aldığı alan: Osmaniye'nin Kadirli ve Düziçi ilçeleri ile Kahramanmaraş'ın Andırın ilçesinin Ceyhan boyundaki köyleri.

2. Aşağı Ceyhan Havzası: Bu bölge, barajın sulama ve taşkın önleme gibi olumlu etkilerinin hissedildiği bölgedir.

3. Orta ve Yukarı Ceyhan Havzası: Aslantaş Baraj Gölü'nün bitiminden itibaren Ceyhan Nehri üzerindeki diğer barajları da içine alan ve Ceyhan'ın kaynağına kadar yer alan bölgedir.

Çağlar, Aslantaş Barajı’ndan etkilenen yerleşim yerleriyle ilgili şu bilgileri verir:

"Baraj rezervuar alanında kalan arazinin bölgedeki toplam 18 köye ait olduğu tespit edilmiştir. Bu köylerden, yerleşim merkezleri ile arazilerinin toplamı su altında kalan köy sayısı 6'dır. Ayrıca bu 18 köye ait 18 mahalle (köy merkezleri hariç) de baraj rezervuar alanında kalmıştır. Diğer yerleşim merkezi su altında kalmamış olan köylerin (12 köy) arazileri, kısmen veya tamamen, rezervuar altında kalmış ve dolayısıyla kamulaştırmaya konu olmuştur." (Çağlar, 2002, s. 61).

Aslantaş Baraj Gölü altında kalan köyleri şu şekilde sıralamak mümkündür: Andırın'a bağlı Üzücek ve Düziçi'ne bağlı Çerçioğlu köyleri tamamen; Andırın'ın Kıyıkçı, Gökahmetli, Köleli, Dırdıbıtlı (Erenler) köyleri ile Kadirli'nin Karatepe ve Düziçi'nin Pirsultanlı köylerinin yerleşim yerlerinin ve tarlalarının bir kısmı Aslantaş Barajı altında kalmıştır (Çağlar, 2002, s. 50, 51).

Aslantaş Barajı sebebiyle maddi kayba uğrayan halka, devlet; DSİ aracılığı ile iki seçenek sunmuştur: Birincisi hak ettikleri kamulaştırma bedellerini alarak başlarının çaresine bakmak, diğeri ise devlet tarafından yeniden yerleştirilmektir.

Sahada, köylerinden ayrılmayan; saha dışında da köylerinden ayrılmak durumunda kalan vatandaşlarla yaptığımız görüşmelerde maddi kayıplarının karşılanıp karşılanmadığı ile ilgili sorumuza, 
tamamına yakınından olumsuz yanıt alınmıştır. Ödenen istimlâk bedellerinin hem değerinde ödenmediği hem de geç ödendiği belirtilmiştir. Niçin hak aramadıklarıyla ilgili sorulara ise verilen ortak cevapta; hem devleti kutsal görerek şikâyet etmek gibi bir düşünceye sahip olmadıklarını hem de hak aramak için hangi merciye, nasıl başvurulacağını bilmediklerini, kendilerine yol gösteren olmadığını belirtmişlerdir (K.3, K.4).

Barajdan etkilenen köylülerden bazıları su tutulmadan önce, bazıları da su tutulduktan sonra ya köylerinin yüksek kesimlerine ya da Kadirli, Düziçi, Osmaniye, Andırın, Kahramanmaraş, Adana gibi yakın şehirlere yerleşmişlerdir. Bunda asıl sebebin hem geçimlerini sağlama hem de memleketlerinden çok uzaklaşmama isteği olduğu bilinmektedir. Ulaşımın daha zor olduğu Kahramanmaraş ise yerleşim için çok fazla tercih edilmemiştir.

Andırın'ın Köleli, Kıyıkçı, Gökahmetli köyü ile Kadirli'nin Kızyusuflu, Bahadırlı, Durmuşsofulu köyü sakinlerinden bir kısmı, köylerinin baraj suyu gelmeyen üst kısımlarına yeni bir yerleşim yeri oluşturmuş ve burada yaşamlarını sürdürmektedir. Köylerinde kalmayan az bir kesim; Bektaşl1, Tokmaklı (Yeşilova) gibi yakın köylere yerleşmiştir. Kendi imkânlarıyla göç edenler ise Kadirli, Düziçi, Osmaniye ve Adana'ya yerleşmişlerdir. Andırın'ın Göçmenler ve Gum Galası (Kum Kalesi) sakinlerinin tamamı köylerinden göç etmiş, köylerinde yeni bir yerleşim yeri oluşturmamıştır. Göçmenler köyünden göç edenlerin büyük çoğunluğu gönüllü olarak Ceyhan'ın Büyükmangıt köyü ile Adana Sarıçam'a yerleşmiştir. Gum Galası (Kum Kalesi) sakinleri ise Kadirli’ye yerleşmiştir. Düziçi tarafından tamamen su altında kalan Metlioğlu bucağı ile Çerçioğlu köyü sakinleri, Düziçi ve Osmaniye'ye yerleşmişlerdir (K.1, K.2). Göçmenler ve Gökahmetli'den zorunlu yerleşime tabi tutulanlar ise Kahramanmaraş'ın Ferhuş köyüne yerleştirilmiştir (Çağlar, 2002, s. 51).

Baraj, bölgenin iklim özelliklerini de değiştirmiştir. Hava sıcaklığının daha da artmasına bağlı olarak kış aylarında kar yağışı görülmemeye, su birikintileri buz tutmamaya başlamıştır. Barajın yakınındaki köylüler, yaz aylarının eskiye göre daha sıcak ve bunaltıcı olduğunu ifade etmektedir. İklimin değişmesi bitki örtüsünü de etkilemiştir. Bitkiler erken yaprak dökmeye, hastalık kapıp kurumaya başlamıştır (K.12).

Alptekin'in (2011, s. 308) tespitlerine göre, baraj sular1 oluşmadan önce bu alanlarda yerleşim yerleri vard1. Günün birinde bir yetkili gelerek buraların terk edilmesini istedi. Göçle birlikte altı ahır ve samanlık, üstü ev olan bina gibi maddi kültür değerleri geride 
bırakıldı. Hiçbir kıymeti yok gibi görünen evler, aslında halk mimarisinin bir kültür değeridir. Evlere asılan koç, keçi, kurt, at, köpek başı ve at nalı gibi nesnelerde İ́lamiyet öncesinden süzülerek gelen bir kültür yatmaktadır.

Barajların yapımı bölgedeki konargöçerleri de etkilemiştir. Çukurova bölgesi konargöçerlerinin kışlak ya da konalga olarak kullandıkları yerlerden ve bu yerlere ulaşmak için kullandıkları göç yollarından bazıları ya da bunların bazı bölümleri baraj altında kalmış ve bu hayat biçimini sürdürenler farklı yer ve yol arayışına girmek zorunda bırakılmıştır (Doğaner, 2013, s. 46, 97, 136, 137). Aslantaş Barajı'yla birlikte, yüzyıllardır kullanılan ve Akyol (Ă̆ Yol) olarak bilenen ticaret ve göç yolu da sular altında kalmıştır (K.5).

Ersoy, barajdan etkilenen Karatepe köylüsünün sosyo-ekonomik durumundaki değişimi şu cümlelerle açıklamaktadır:

"Karatepe, Osmaniye il merkezine $30 \mathrm{~km}$ mesafede olup, doğusunda Düziçi ve Bahçe, batısında Kadirli ilçeleri bulunan; Millî Park1, Açık Hava Müzesi ve Aslantaş Baraj Gölü ile çevrili şirin bir köydür... Tam olarak yerleşik hayat düzenine geçen Türkmenler, hayvancılığın yanı sıra zamanla tarımla da uğraşmayı öğrenip Anadolu köylüsü olmuşlardır. Türkiye Cumhuriyeti'nin kurulması ve kalkınma hamlesinin başlamasıyla birlikte bölgeye bir baraj gölü yapılması kararı alınır. Bu durum Karatepe köylüsünün tarım arazisinin, Aslantaş Baraj Gölü altında kalmasına neden olur. Köylü için geride tek geçim kaynağı olarak küçükbaş hayvancılık kalır. Bir müddet sonra bölgede Anadolu Medeniyetleri araştırmaları kapsamında kazılar başlar ve bulunan medeniyet kalıntıları ile tabiat dokusunun bozulmaması gerekçesiyle bölge Millî Park alanı ilan edilir. Böylece Karatepe köylüsü tek geçim kaynağı olan küçükbaş hayvancılığı da yapamaz olur." (Ersoy, 2003, s. 1, 4).

Andırın'ın Köleli köyünden olan Halil Aslantaş'ın “Aslantaş Barajı Neleri Yuttu?" adlı eserinde konuyla ilgili şu olumsuz ifadelere yer verildiği görülmektedir:

\footnotetext{
"Yukarıdan bakıldığında, bir tarafında Akdeniz’e kadar uzanan verimli Çukurova toprakları, diğer tarafında Toros dağlarının eteğindeki yeşil ormanların arasında mavi boncuk gibi görünen Aslantaş Barajı, çekici renklere sahip zehirli yılanlar gibi, binlerce kilometrekarelik alandaki, tüm canlı ve cansızları bir daha dönmeyecek şekilde yutarak doymak bilmez midesine indirdi. Bununla da yetinmedi, binlerce insanın yetişmesine destek olan mazisini, gelecek nesillere aktaracağı ümidini, ataları ile çocuklarının bağını sağlayacak olan tarihini de yuttu. Benim ise kuş sapanımda kullandığım çakıl taşlarımı, misket yaptığım renkli taşlarımı, çırılçıplak içinde yüzdüğüm, susayınca suyunu içtiğim su kaynağımı,
} 
güneşlendiğim kumsalımı ve çiğneyerek suyunu emdiğim meyan köklerimi yuttu.” (Aslantaş, 2015, s. 210).

Düziçili araştırmacı İşlek'in barajın yapılması hakkındaki görüşleri şöyledir:

"Aldığı gencecik kurbanların ahı mı tuttu, kurbanlara yakılan ağıtlardaki dualar mı yerini buldu nedir, baktık ki bir gün Ceyhan, Aslantaş Barajı'nın suları altında kalıvermiş̧ ve kurban aldığı akranlarımız gibi boğulmuş. Ceyhan'ın barajda boğulmasına da, akranlarımızın Ceyhan'da boğulmasına üzüldüğümüz kadar üzülmüştük." (İşlek, 2010, s. 23).

İşlek'e göre barajın yapımı sadece insanları değil; dağı, pınarı, bitkileri, kuşları da olumsuz yönde etkilemiştir:

"Barajla birlikte köydeki bütün büyü bozuldu. Hemen herkes akraba idi. İmkânı olanlar ilçeye göçtü. Düldülcük Dağımız, Narlık'taki çift oluklu, başına çifte serviler diktiğimiz ve sularında 'Avarlık' (sebzeler) yetiştirdiğimiz pınarımız mahzun oldu. Cinli Mazı, Günyüzü, Karadut, İnceboyun mahzun oldu. Çukurova'nın en güzel pamuklarının yetiştiği Bucak ${ }^{2}$ 'taki tarlalar ise, barajın altında kaldı. Tepeden tepeye söylenen Karacaoğlan, Dadaloğlu, Köroğlu, Elbeylioğlu türküleri sustu. Kekliklerle, Çukurova'nın öz kuşu turaçlar sustu. Davullar da sustu. Köy derin bir sessizliğe büründü.” (İşlek, 2010, s. 29).

Barajda su tutulmaya başlanmasıyla, yerleşim yerleriyle birlikte mezarlıkların da su altında kalacağı gerçeği, köylüleri çeşitli arayışlara itmiştir. Mezarların taşınması konusunda halk, resmî makamlardan destek görmemiştir. "DSİ, mezarlıkların kamulaştırma bedelini köylülere ödediğini belirtmiştir. Ancak onların mezarlarının taşınması konusunda hiçbir hizmet verilmemiştir.” (Çağlar, 2002, s. 95).

Andırın'a bağlı Köleli köyü sakinlerinden imkânı olanlar, suyun altında kalacak mezarlarını köyde yeni oluşturulan ve Küçük Babı (Totunlugöl) denilen yere taşımışlardır. Bunun yanında, bu köyde çok eskiden kalma Ulu Mezar olarak bilinen yerdeki mezarların hiçbirinin sahibi/yakını olmadığı için, Ulu Mezar barajla birlikte tamamen su altında kalmıştır. Köleli köyü sakinlerinden bir kısmı, barajın yapılacağı belli olduğu için, barajın suyu tutulmadan, yakın köylerden Anacık köyündeki Armutlu Mezarlı̆̆ı’na, Somaklı köyündeki Şehitler Mezarlığı'na yakınlarını defnetmişlerdir. Günümüzde de bu mezarlıklara, Köleli köylülerinden defnedilenler olabilmektedir. Düziçi tarafindan ise Metlioğlu bucağı denen yerleşim yeri ve bunların mezarları tamamen su altında kalmıştır. Gum Galası (Kum

\footnotetext{
${ }^{2}$ Metlioğlu bucağı, Düziçi tarafındadır ve tamamen baraj gölü altında kalmıştır.
} 
Kalesi) denilen yer de tamamen su altında kalmıştır ve bunların mezarları zaten azdır ve Karatepe'ye taşınmıştır (K.1).

Yine Andırın'a bağlı Gökahmetli, Kıyıkçı köylerindeki mezarlardan bir kısmı Ümmetli köyü mezarlığına, baraj basmadan taşınmıştır. Bu köylerdeki mezarların büyük çoğunluğu su altında kalmıştır. Baraj baskınından sonraki defin işlemleri ise Kıyıkçı ve Gökahmetli'nin yeni oluşturulan yerleşim yerlerindeki yeni mezarlara yapılmaktadır. Göçmenler köyünün yerleşim yeri ve mezarlığ tamamen su altında kalmış ve buradaki mezarlar başka bir yere nakledilememiştir (K.2).

Aslantaş Barajı'nın altında kalan mezarlarla ilgili Köleli ve Gökahmetli; Kadirli'nin Hacıabdılar, Cennetler köyünden vatandaşlarla yaptığımız görüşmelerde, mezarlarını bazı ailelerin kaldırdığı, kaldırmayanların ise çoğunlukta olduğu bilgisine ulaşılmıştır (K.1, K2, K.3, K.8, K.9, K.10, K.13).

Belki de ilk kez karşılaştıkları mezar taşıma konusunda halk, dinî hükümleri bilmediğinden ve gelenek de oluşmadığından kararsızlık yaşamıştır:

"Yapılan mülakatlarda, ev ve arazileri rezervuar alanında kalan Bulgaristan göçmeni Kıyıkçı Köyü Üzücek Mahallesi sakinlerinin mezarlarını rezervuar alanında bıraktıkları tespit edilmiştir. Sadece 2-3 kişi mezarlarını suyun ulaşmayacağı yere taşımıştır, diğerleri ise, kendileri ile yapılan mülakatlardan anlaşıldığı kadarıyla, mezar taşımanın mı yoksa taşımamanın $\mathrm{m} ı$ günah olacağı konusunda bilgileri olmadığı ve bu konuda başkasından da bilgi almadıkları için mezarları taşımamanın daha uygun olacağına karar vermişlerdir." (Çağlar, 2002, s. 95).

Devlet tarafından vatandaşlarına fayda sağlayacağı düşünülerek inşa edilen diğer yapılar gibi Aslantaş Barajı da olumlu düşüncelerle inşa edilmiştir. Çağlar, projeyle hedeflenen faydaları şöyle açıklamaktadır:

"Projenin gerçekleşmesi halinde artacak tarımsal üretim yolu ile 12.000 çiftçi ailesine fayda sağlayacağı öngörülmüştür. Projenin 4.000 civarında aile için tarımsal faaliyetlerde bulunmak üzere 14.000 adam/yıl istihdam olanağ1 yaratacağı öngörülmüştür. Bu bağlamda projenin gelir dağılımının iyileştirilmesini sağlamaya çalışmakla birlikte, 1.000 civarında ailenin yerlerinden edilmesine neden olacağ da belirtilmiştir." (Çağlar, 2002, s. 49).

Aslantaş Barajı'nın az da olsa olumlu etkileri olmuştur. Baraj bölgedeki turizm faaliyetlerini canlandırmıştır. Baraj kıyısına piknik alanları, kayıkhane yapılmış ve baraj gölü çeşitli su sporlarına mekân oluşturmuştur. Ayrıca, T.C. Gençlik ve Spor Bakanlığına bağlı, 310 
dönümlük bir alana konaklama imkânları da olan Aslantaş Gençlik Kampı inşa edilmiştir. Kamp, Türkiye'nin farklı yerlerinden katılan genç gruplara yılın her günü dönüşümlü bir şekilde hizmet vermektedir. Karatepe köyünden birçok vatandaş, baraj inşasında ve baraj tamamlandıktan sonra Aslantaş Barajı'nda görev alıp emekli olmuşlardır. Böylece hem geçimlerini sağlamışlar hem de sosyal güvenceye kavuşmuşlardır (K.13).

Aslantaş Baraj gölünde balıkçılık da yapılmaktadır. Aslantaş Barajı'nda avlanan balıkları haftanın birkaç günü Osmaniye’ye bağlı Hacı Dağı Fenk Yaylası'nda pazarlayan balıkçılar vardır (Koca, 2017, s. 61).

1973 yılında yapımına başlanan Aslantaş Barajı, film çekimlerinde mekân olarak kullanılmıştır. 1977 yılı yapımı olan "Selvi Boylum Al Yazmalım” filminin Osmaniye'deki çekimleri için filmin yapımcısı olan Abdurrahman Keskiner, Aslantaş Barajı'nda 80 kişilik yer ayırttığını ve aşağı yukarı kırk gün burada çalıştıklarını (Evren, 2012, s. 114) ifade etmiştir.

\section{ASLANTAŞ BARAJI'NIN HALK ŞIIIRINDE KONU EDİLMESİ}

Halk şiiri; içinde halka ait olan unsurları barındıran, halk dilinin kullanıldığı şiirlerdir. Aslantaş Barajı özellikle olumsuz etkileri ile halk şiirine yansımıştır. Aslantaş Barajı yapıldıktan sonra insanların sosyo-ekonomik durumlarında yaşanan değişimi halk şiirinde görmek mümkündür. Hacı Musa Tuncer'in Köleli Göl Altında 1 ve Köleli Göl Altında 2 adlı şiirlerinde, Hacı Mehmet Dereli'nin Aslantaş Barajı ${ }^{3}$ şiirinde ve İ. Muzaffer Çağlayan'ın Aslantaş Barajı (Çağlayan vd. 2000, s. 221) şiirinde baştan sona Aslantaş Barajı konusu işlenmiştir. Baraj gölü altında kalan köylere duyulan özlem de şiirlerde işlenmiştir. Abdullah Arslantaş'ın Andırın ${ }^{4}$ şiirinde bu türden bir özlem dile getirilmiştir.

Bunun yanı sıra bölgeyle ilgili halk şiirlerinde Aslantaş Barajı konusuna değinilmiştir. Makalemizde söz konusu şiirlerin tamamını

\footnotetext{
${ }^{3}$ Şiir, Dırdıbıtlı (Erenler) köyünden Hacı Mehmet Dereli'ye aittir. Ahmet Özdemir, bu şiiri Mehmet Erkoçak'a vermiştir. Mehmet Erkoçak da, şair Hacı Musa Tuncer'e (K.8) köyüyle ilgili olduğu için vermiştir. Saha çalışmamızda bu şiir, Hacı Musa Tuncer'den alınmış̧ırır.

${ }_{4}^{4}$ Andırın ilçesinin Köleli köyünden olan, Gondal Paşa lakabı ile bilinen Abdullah Arslantaş (K.1), kendi tabiriyle baraj kaçkınlarındandır. Çeşitli dörtlüklerini örnek olarak aldığımız şiirde hasret çekilen her şey, Aslantaş Barajı kaynaklıdır.
} 
vermek yerine, yine barajla ilgili çeşitli yönlere değinilen dörtlüklere örnek olarak yer verilmiştir.

1983 yılında Aslantaş Barajı’nın yapımı tamamlanmıştır. Barajın yapımı "kara kader" olarak nitelendirilmiştir:

"Tuncer uzak gitme, beri gel beri,

Seksen üçte aldın acı haberi,

Mevlâ'm layık görmüş kara kaderi,

Alnımda yazımdır nar'ın Andırın.” (Hacı Musa Tuncer, Andırın).

Baraj yapımından doğrudan etkilenmeyen kişilerin ilgisizliğine dikkat çekilmiştir:

"Y1l seksen üç baraj bastı yurdumu,

Göçen köyler hiç zihnini yordu mu?

Komşu muhit merak edip sordu mu?

Coşkun selden kaçmayalı çok oldu.” (Hacı Musa Tuncer, Çok Oldu).

Tarlaları su altında kalıp göçmek zorunda kalan ve aileleri dağılan köylüler mutsuzdur. Bunları yaşamayıp sadece barajın faydalarını görenler ise durumdan hoşnuttur:

"Köyler zorla göçtü, göl oldu ova,

Dertler yumak yumak, dağıldı yuva,

$\mathrm{Bu}$ iş sana yarar, gül Çukurova,

Var mıdır bu işte kâr'ın Andırın?” (Hacı Musa Tuncer, Andırın).

Aşağıdaki dörtlükte barajın tamamlandığı tarih daha ayrıntılı verilmiş ve barajın tamamlanmasıyla insanların acı çekmeye başladığı anlatılmıştır:

“Seksen üç Kasım'ı belli bir gündür

Tamam oldu baraj, kapıyı indir.

Kasım'ın dokuzu, bu işler sondur.

Gözyaşları akışmaya başladı." (Hacı Mehmet Dereli, Aslantaş Barajı).

Barajın yapımına karar verenler eleştirilmiştir:

"Baraj yapan beyler işlemiş haltı,

Verimli topraklar puturak, yıltt,

Biçmetaş'tan öte çamların altı, Köy).

Serilidir şimdi pür köyümüzde." (Hacı Musa Tuncer, Anadolu'da Bir

Kıyıkçı Köyü (Aslantaş Barajı)'nün Ağıdı 2'nin hikâyesinde Andırın'ın Kıyıkçı köyünün tarlaları barajla birlikte su altında kalır. Biri Kıyıkçı'dan olan iki yaşlı adam herkes gibi tarla parasını almak için 6. Bölge Su İşleri Müdürlüğüne gider. Birkaç kez gitseler de bir şey alamadan geri dönerler. En sonunda canı yanan adam; 1946'da Arslantaş Barajı'nın olduğu yere gelen, Karatepe adıyla da bilinen 
yerde kazı çalışması başlatarak "Geç Hitit" dönemine ait eserlerin ortaya çıkarılmasını ve daha sonra bölgede 7000 dönüm arazinin millî park yapılmasına aracı olarak Karatepe'de açık hava müzesinin kurulmasını sağlayan Halet Çambel'e yönelik olduğu düşünülen bir ağıt söyler (Temiz, 2005, s. 693). Ağıdın ilk dörtlüğ̈̈ şöyledir:

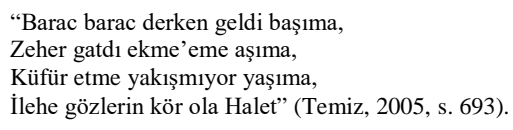

Andırın'ın ileri gelenlerinin baraj yapımına engel olmadığını vurgulayan şair bu durumdan yakınmaktadır:

"İleri gelenler olmadı engel,

Pekmezini kime satacak Döngel ${ }^{5}$ ?

Tuşa gelmez idin attılar çengel,

Belin kırık şimdi sarın Andırın...” (Hacı Musa Tuncer, Andırın).

Barajın yapılması, insanlara kurulan bir tuzak olarak görülmüştür:

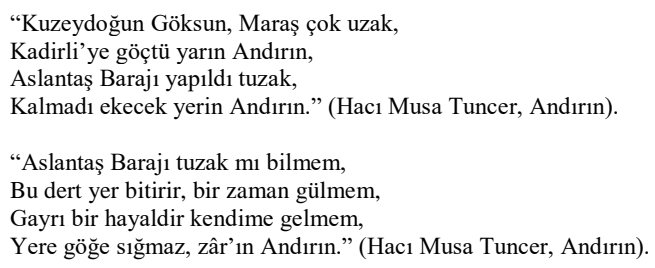

Karatepe'ye yapılan baraj, azgın Ceyhan Nehri’nin önünü çevirmiştir. Ket vurulan azgın su, ovaları doldura doldura gerisin geriye gelmektedir. Bundan etkilenen yerleşim yerleri üzgün, su altında kalan yerler ise bozgundur. Baraj altında kalma, "mezara girmek" olarak nitelendirmiştir:

"Karatepe suyu çevirdi azgın,

Tokmaklı, Anacık, Üzücek üzgün,

Köleli köyüne uğradı bozgun,

Mezardan kalkamaz yarın Andırın.” (Hacı Musa Tuncer, Andırın).

Andırın'a bağlı Köleli köyünün karşı yamacı Düziçi'ne bağlı Metlioğlu bucağıdır. Metlioğlu ve Köleli birbiriyle akrabadır. Barajın tutulmasıyla Köleli ve Metlioğlu sular altında kalacaktır. Köleli

\footnotetext{
${ }^{5}$ Döngel; Kahramanmaraş merkeze bağlı bir köydür. Bu köyün çerçileri meşhurdur. Bu çerçiler, Andırın'ın Ceyhan Nehri boyundaki köylere ürün satarak geçimlerini sağlamaktadır. Barajla birlikte Döngelliler de geçim kaynaklarını kaybetmişlerdir.
} 
köyünden olan Mahmut Arık (Danacı Mahmut), hem Birinci Dünya Savaşı'na hem de Kurtuluş Savaşı'na katılmış bir kahramandır. Danac1 Mahmut'un Osmaniyeli Rahime Hatun'u Fransız kurşunlarından kurtardığını, köylüleri onun anlatılarından bilmektedir. Vatan için savaşmış bir kişi olan Danacı Mahmut'un mezarı da suyun tutulmasıyla baraj gölü altında kalacaktır. Bu durum, köylüleri için ayrı bir hüzün sebebidir. Su gelmeye başlayınca Danacı Mahmut'un mezarı, akrabaları ve köylüleri tarafından yakın köylerden Anacık'ın Armutlu Mezarlığı'na taşınır (K.9).

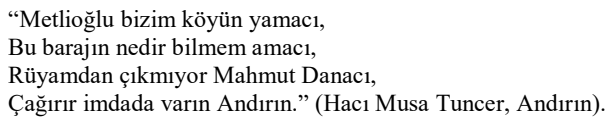

"Metlioğlu bizim köyün yamac1,

Bu barajın nedir bilmem amac1,

Rüyamdan çıkmıyor Mahmut Danacı,

Çağırır imdada varın Andırın." (Hacı Musa Tuncer, Andırın).

Baraj yapılmadan önce halkın çiftçilik yaptığı anlatılmaktadır. Barajla birlikte ırmağın göle dönüşmesi de son iki dizede anlatılmakta, baraj gölü deniz olarak adlandırılmaktadır:

"Elde ellik orak, ekin biçerdik,

Ceyhan suyun zemzem diye içerdik,

Bazen yüzer bazen çemrer geçerdik,

Şimdi deniz oldu derin Andırın.” (Hacı Musa Tuncer, Andırın).

“Irmak iken göle dönmek” sözü, yaşanan değişimi çok güzel özetlemektedir:

“Andırın'da Köleli'dir köyümüz,

Irmak iken göle döndü suyumuz,

Vade yokken kazılırsa kuyumuz,

Dostlar dua etsin salıma gardaş." (Hacı Musa Tuncer, Gardaşa Mektup 2).

Sariye Gök (K.6), 1983'te baraj tutulurken söylediği aşağıdaki dörtlükte, yıllardır ekip biçtikleri tarlaların sular altında kalmasından duyduğu üzüntüyü dile getirmiştir:

"Ötmez oldu eski öten düdüğüm,

Anam babam ekmeğini yediğim,

Ekip biçip tarlasını sürdüğüm,

Dönüm dönüm su altında kalıyo."

Barajla birlikte tarla ve bahçeler su altında kalmıştır:

"Atamız yatağı Köleli vardı.

Barajın altına sızarken gördüm,

Tarlası, bahçesi, Ceyhan'ı vardı,

Şimdi harmanları bozarken gördüm.” (Hacı Musa Tuncer, Köleli Göl Altında 1). 
Barajdan sonra köyünü terk edenlerin nerede ölecekleri, mezar yerlerinin neresi olacağı belli değildir. Verimli tarlaları göl altında kalacak ve geçimleri bitecektir:

Alnımıza haktan böyle yazılı,

Bilmem mezarımız nerde gazılı.

Etirafı selvi, kavak dizili

Altın kesen tarlalarım göl oldu ${ }^{6}$ (K.11).

İnsanların evleriyle birlikte, hayvanları için yaptıkları yerler de su altında kalmıştır. Hayvanları böylece, sahiplerine yük olmuştur. Bir zamanlar yaşadıkları yerler, deniz canlılarının yuvaları olmuştur:

"Felek vurdu yıktı benim tüneğim,

Başıma yük oldu danam, ineğim

Ak sıvaklı kiremitli konağım,

Balıklara, tusbalara yem oldu” (K.11).

İnsanlar, yurtlarını terk ederken evlerinin işe yarayabilecek kapı, pencere, demir, çinko gibi kısımlarını söküp götürmüşlerdir:

"Bomboş Kayaönü solmuş gülleri,

Köleli'den esmez olmuş yelleri,

Viran olup yıkılınca evleri,

Bağlanmış yolların kalmış Köleli.” (Hacı Musa Tuncer, Köleli Göl Altında 2).

"Masmavi sulara gömülmüş ovan,

Yıkılmış evimiz galmamış yuvan,

Gücün varsa gardaş dayan ha dayan,

Şimdi gırıldı mı belin Andırın?” (Abdullah Arslantaş, Andırın).

Adil Gök (K.3), aşağıdaki dörtlüğü 1983'te baraj tutulurken söylemiş, üzüntüsünden gerisini getirememiş ve hüngür hüngür ağlamıştır. Dörtlügün üçüncü dizesinde evlerin çatılarında kullanılan çinkonun ovada parladığı dile getirilmiştir:

Harp1l harpıl mor üçgülü yiyerek

Hoșur hoșur süt verirdi inekler.

Parıl parıl ovalarda parlarken

Takır takır sökülüyor konaklar.

\footnotetext{
${ }^{6}$ Mehmet Keskin (K.11), kaynaklık ettiği üç dörtlükten oluşan şiiri nasıl öğrendiğini şöyle anlatmaktadır: "1981 yılında Haruniye tarafından Andırın tarafına kayıkla geçtik. Beşbucak köyüne gidecektik. Köleli'den öte yayan gidiyoruz. Kızılkaya denen yere vardığımızda bir çoban gördük. Yolun kenarına oturmuş, eli kulağa atmış, bunu söylüyordu. Yanına oturduk. Ben de teyp gibi hafizama kaydettim, unutmadım."
} 
Özel mülklerle birlikte cami, okul gibi kamu binaları da sökülmüştür:

“Gökahmetli köyü göçtü ormana

Karşı gelinmiyor yüce fermana

Gayret edin, siz de gelin dermana Baraj1).

Cami, okul sökülmeye başladı." (Hacı Mehmet Dereli, Aslantaş

Kur’an kursunun su ile dolması dile getirilmiştir:

“Baraj oldu Andırın'ın ovası

Kur'an Kursu'muz da balık yuvası

Çölde gezer zenginlerin devesi Baraj1).

Sıpa merkep yatışmaya başladı.” (Hacı Mehmet Dereli, Aslantaş

Gökahmetli köyünün camisi baraj altında kalmıştır ve suyun üzerinde minarenin yarısı görülebilmektedir. Minarenin bu kısmı da yıldırım düşmesi sonucu yıkılmıştır:

“Köleli, Metl'oğlu, Erenler üzgün,

Üzücek, Göçmenler, Tahtalı bozgun,

Gökahmetli kayıp, göl olmuş azgın,

Camisiz minare uzarken gördüm.” (Hacı Musa Tuncer, Köleli Göl Altında 1).

Sadece insanın mekâna özlemi değil, mekânın da insana özlemi sanatlı bir şekilde dile getirilmiştir. Ölen kişinin yasını baraj altında kalan konağı tutmaktadır. Baraj altında kalanların beli kırılmıştır; çaresizdir ve muhtaç durumdadır. Köleli köyünden saygın bir kişi olan Muhtar Ahmet'e ait konak da sular altında kalmıştır:

"Barajda yas tuttu ünlü konağın,

Kurulmuş kenara abdest yunağın,

Civıltısız kalmış bahçenle bağın,

Dillerde ağıtlar, kırık bel artık." (Hacı Musa Tuncer, Kurtbeyoğlu Demircioğlu).

İnsanlar üzüntü içerisinde ağlamaktadır:

"Masmavi göl olmuş köyler, ovalar,

Ağlıyor insanlar gözün ovalar,

Azgın dalga, bizi yurttan kovalar,

Üstünde kayıklar yüzerken gördüm.” (Hacı Musa Tuncer, Köleli Göl Altında 1). 
İnsanların hayalleri, geleceğe dönük planları yok olmuştur:

“Kayıp olmuş Metl'oğlu'nun bucağı,

Göç etmişler, tütmez olmuş ocağı,

Ceyhan, Sabun ${ }^{7}$ ile dolmuş kucağı,

Sular, hayalleri çalmış Köleli.” (Hacı Musa Tuncer, Köleli Göl Altında 2).

Baraj gölünün kapladığı alan ayrıntılı olarak anlatılmıştır:

"Silelenmiş Üzücek' in yazısı,

Zâten gitmiş Andırın'ın yarısı,

Tokmaklı'ya ulaşmasın darısı, 2).

Ora uğrak yeri salmış Köleli.” (Hacı Musa Tuncer, Köleli Göl Altında

Baraj gölü, Andırın'ın ova kesimini âdeta yutmuştur:

"Armutlu mezarllğı uludur ulu,

Andırın'1 yuttu barajin suyu,

Misafiri sever Köleli köyü,

Bir gece misafir olun turnalar." (Abdullah Arslantaş, Turnalar).

Barajla birlikte tabiatın kokusu da güzelliğini kaybetmiştir:

"Kara Paşa, Çaylı çekti göçünü

Allah bağışlasın olan suçunu

Mundar üleş aldı gölün içini Baraj1).

Balçık, çamur kokuşmaya başladı" (Hacı Mehmet Dereli, Aslantaş

Göçmek zorunda kalan insanların toplumsal statüleri değişmiş ya da yok olmuştur:

"Nere gitti bu köylerin beyleri?

Traktörle sürülürdü yerleri,

Üzdü amma Hacı Musa Tuncer'i,

Bakıp beti benzi solmuş Köleli” (Hacı Musa Tuncer, Köleli Göl Altında 2).

Barajın insanların ekonomik durumuna etkisi konu edilmiştir. Köylülerin aldığı istimlâk bedelleri çabucak bitmiştir:

“Ilıca'yla Aslantaş'ın arası,

Azd1 gayrı bu köylerin yarası,

Tükenince istimlağın parası,

Anladım bir kötü 'hâl'miş Köleli.” (Hacı Musa Tuncer, Köleli Göl Altında 2).

\footnotetext{
${ }^{7}$ Sabun: Düziçi tarafindan gelip Ceyhan Nehri’ne karışan akarsuyun adı.
} 
Barajın yapılması, ulaşım biçimi ve araçlarını da etkilemiştir. Ceyhan Irmağı üzerinde Andırın'ın ova kısmındaki köyleri ile DüziçiOsmaniye arasındaki ulaşım, Aslantaş Barajı'ndan önce gemi adı verilen taşıt ile sağlanmaktaydı. Aslantaş Barajı'nın yapımı ile gemicilik bitmiş ve Geminin Ağzı denen yer de sular altında kalmıştır:

“İsim şöyle idi; 'Geminin Ağzı'

Mevkisi Üzücek, uğrardım bazı,

Orda yaşam başka, alırdım hazı,

Yazıyı yabanı kazıp geçtiler.” (Hacı Musa Tuncer, Umut Gemisi).

Gemi, köyleri baraj altında kalan son yolcusunu da ırmağın karşısına geçirdikten sonra yıllardır yerine getirdiği görevini tamamlamıştır:

"Bu gemi son göçe kürek salladı,

Kalana, gidene selâm yolladı,

Yâreni yâr bildi, dostu kolladı,

Barajla düzeni bozup geçtiler.” (Hacı Musa Tuncer, Umut Gemisi).

Artık gemi batmış, anılarda kalmıştır:

"Elma erik bahçeleri söküldü,

Talan oldu yaprakları döküldü,

Gemi battı tahtaları büküldü,

Tecirli’ye ${ }^{8}$ geçmeyeli çok oldu.” (Hacı Musa Tuncer, Çok Oldu).

Ulaşım güzergâhı da barajla birlikte değişmiştir:

"Haziranda ekinleri biçerdik,

Yaz gelince yaylasına göçerdik.

Kar yiyerek soğuk suyun içerdik,

Tarihe garıştı yolun Andırın." (Abdullah Arslantaş, Andırın).

Halk şiirinde, haberci bir kuş özelliğiyle yer verilen turnalara insanların kullandığı güzergâh takip ettirilir. Turnalar artık baraj altında kalan Köleli'yi ancak sorarak bulabilecektir:

“Osmaniye üstü Harnı'ya varın,

Boyalı'ya varınca Köleli'yi sorun,

Barajın gölünde bir mola verin, Turnalar).

Gondal Memmet ${ }^{9}$ evde mi, sorun turnalar." (Abdullah Arslantaş,

Bunun yanında turnaların uğrayacağı yerlerden birisi de baraj gölü olmuştur:

\footnotetext{
${ }^{8}$ Eskiden Andırınlılar, Düziçi'ne bir aşiret ismi olan Tecirli derlerdi.

${ }^{9}$ Şairin amcası olan Gondal Memmet, evi baraj altında kaldığından köyün yeni kurulan yerleşim yerine bir ev yaptırmış ve köyde yaşamaya devam etmiştir.
} 
"Yorulmayın Karatepe yolunda,

Fazla eğleşmeyin baraj gölünde,

Sizi bekleyen var Maraş elinde,

Hasretle gözyaşı saçın turnalar" (Âşık Feymânî, Turnalar), (Âşık Feymânî, 2015, s. 161).

Yakınlarına ait mezarların su altında kalması insanları oldukça üzmüştür:

"Gökahmetli'yi koymam sıradan,

Dursun Ağa göçtü, gitti buradan,

Sabır versin yeri göğ̈̈ yaradan,

Göl altında kaldı ölüm Andırın.” (Abdullah Arslantaş, Andırın).

Baraj altında kalan Köleli köyü mezarlığının yeri değişerek yeni mezarlık yeri, Küçük Babı adı verilen mevki olmuştur:

"Köyler nasıl almış intizarını?

Deryaya gark oldu çekti zârını,

Duâ ettiğimiz tüm mezarını,

Tâ Küçük Babı’ya kazarken gördüm.” (Hacı Musa Tuncer, Köleli Göl Altında 1).

Gurbette ölenlerin cenazelerini memleketine defnetmek bir gelenektir. Köyler baraj altında kalınca bu mümkün olamamıştır:

"Silaya umuttu, gurbete köprü,

Üstünden geçene öğretti sabrı,

Çoğunun yâd ele kazıldı kabri,

Geride kalanı üzüp geçtiler.” (Hacı Musa Tuncer, Umut Gemisi).

Aşağıdaki dörtlükte geçen Armutlu, baraj basmayan köylerden Anacık'ın mezarlığıdır. Şairin birçok köylüsü, baraj nedeniyle buraya defnedilmiştir. Şairin annesi ise Osmaniye'nin mezarlığı olan ve yörede Alhanlı adıyla bilinen asri mezarlığa defnedilmiştir. Kendi köyüne defnedilememesi yakınlarını oldukça üzmüştür:

"Babı'da yatana yazarım hece,

Armutlu'ya duam varır her gece,

Alhanlı'da anam, gidiyor güce,

Dağıldı geçmişism sorun Andırın.” (Hacı Musa Tuncer, Andırın).

Mezarlıkları baraj altında kalan köylüler, ölen yakınlarını farklı mezarlıklara defnetmek zorunda kalmıştır. Mezar yerlerinin de insanlar gibi çeşitli yerlere dağılması üzücü bir durum olarak şiirde yer almıştır:

"Yeter Garip Paşa'm bu kadar yeter,

Söyledikçe derde derdimi katar,

Her köylüm bir yerde mezarda yatar,

Hepsinin hatrını sorun turnalar.” (Abdullah Arslantaş, Turnalar). 
Baraj altında kalacak mezarlardan bazıları sökülerek taşınmıştır:

"Sökdük mezarı da kazdık kabiri

Hocalar da okur devir kebiri

Ebu Bekir Sıddık, İslam'ın piri Baraj1).

Münafıklar çekişmeye başladı." (Hacı Mehmet Dereli, Aslantaş

Barajla birlikte bazı köylerin ismi haritadan bile silinmiştir:

"Doğrusu kalmamış köylerin tad1,

Haritadan bile silinmiş adı,

İşte böyle oldu buranın yâdı,

Tuncer’i destanlar yazarken gördüm.” (Hacı Musa Tuncer, Köleli Göl Altında 1).

Köyü baraj altında kalanların "Nerelisin?” sorusuna verebilecekleri cevap, "Ceyhan Nehri'nin yatağı" olmuştur artık:

"Bana 'nerelisin' diyen gardaşım,

Ben Ceyhan Nehri'nin yatağındanım.

Yurdum viran oldu belalı başım,

Şimdi baykuşların öteğindenim.” (Hacı Musa Tuncer, Açık Adresim).

Barajın yapılması bölgedeki insanlar dışında diğer canlı türlerini de etkilemiştir. Turaç, cülkül, cücük gibi kuşlara artık eskisi kadar rastlanmadığı anlatılmıştır:

"Göl oldu arazi giremez araç,

Ücelerde kaldı bir avuç kıraç,

Kepirin kıyında ötmüyor turaç,

Cülkül, cücük uçmayalı çok oldu.” (Hacı Musa Tuncer, Çok Oldu).

Çukurova ile özdeşleşen turaç kuşu, başına gelecek olumsuz durumları hissetmiş gibi ötmektedir. Artık kendisinin büyüyüp uçabileceği bir mekân kalmamıştır:

"Yeşil yurdumuz da hep oldu gölek

Hidayet sendedir yaradan felek

Baskında yurdumuz, biz nerde galak?

Yavru turaç ötüşmeye başladı." (Hacı Mehmet Dereli, Aslantaş Baraj1).

$\mathrm{Bu}$ kuşların yerini, gölde yaşayabilen martı, ördek ve kaz türünden kuşlar almıştır:

“Kul Mehmet'im der de bitti mi sözün?

Bozuktur teller de ötmüyor sazın

Dört mevsimde belli baharın, yazın Baraj1)

Martı, ördek yüzüşmeye başladı.” (Hacı Mehmet Dereli, Aslantaş 
"Uçuşur barajda sıralı kazlar

Seyrana çıkmış da gelinler, kızlar

Gamlı gönüllerde yaşlıdır gözler Baraj1).

Damla damla akışmaya başladı." (Hacı Mehmet Dereli, Aslantaş

Barajın yapılması göçe sebep olmuş, göç de gurbet duygusunu doğurmuştur. Yön artık gurbete dönmüştür:

"Baraj ile tüm emekler dağıld1,

Yaşayan has sevda gölde boğuldu,

Yön gurbete döndü, dertler yığıldı, Gemisi).

Gerçek hayal oldu, gezip geçtiler,” (Hacı Musa Tuncer, Umut

Göçle birlikte sülaleler, geniş aileler dağılmış; farklı yerleşim yerlerine göçmek zorunda kalmıştır:

"Baraj belasından göç etti köyüm,

Çaresiz gurbete dağıldı soyum.

Dadaloğlu emmim, Avşardır boyum, Adresim)

Namerde baş eğmez otağındanım." (Hacı Musa Tuncer, Açık

Göçmek zorunda kalan insanların nereye yerleşebilecekleri de büyük bir sorundur. Kıyıkçı Köyü (Aslantaş Barajı)'nün Ağıdı 1'de bu konunun işlendiği görülmektedir. Andırın'ın Kıyıkçı köyü, Arslantaş Barajı'nın su tutmaya başlamasıyla su altında kalmaya başlar. Bir gün evinde hanımıyla oturan Âşı Süleyman Ateş, evine dalgalar vurmaya başlayınca bir ağıt söyler. Ağıtta, hanımına kendi köylerine göçme fikrini açar. Hanımı ise kardeşlerinin de çok iyi durumda olmadığını, köyünde bol ve çeşitli tarım ürünü elde edilemediğini, işlerinin daha da zorlaşacağı için yaşadığı köyü terk etmek istemediğini dile getirir (Temiz, 2005, s. 691, 692). Ağıt şu dizelerle başlar:

“Allah'ım ya Rabbim nasıl olurum?

Tarlamı baraj basıyor nerde galırım?

On çocuğunan acımdan ölürüm,

Avrat senin vatana göçelim, buradan gaçalım.” (Temiz, 2005, s. 691).

Aşağıda verilen dörtlükte geçen Yazlak Damı; hayvanların otlatıldığı, Köleli köyünün baraj altında kalmayan yüksek kesimidir. Barajın yapılmasından sonra köyden göçmeyen birkaç hane, yeni yerleşim yeri olarak burayı seçmiştir:

"Birer birer dağılmışlar her yana,

Düşünürsen acı gelir insana,

İnek güttüğümüz Yazlak Damı'na,

Şirin bir Köleli düzerken gördüm.” (Hacı Musa Tuncer, Köleli Göl Altında 1). 
Nereye göçüleceği kişilerin ekonomik durumuna göre değişiklik göstermiştir:

“Uruşan Göçmen' de karşı karşıya

Fakir olan göçemiyor çarşıya.

Muhtaç olduk acı suvan, turșuya Baraj1).

Yandı yürek, tutuşmaya başladı.” (Hacı Mehmet Dereli, Aslantaş

Baraj altında kalacak yerlerin, evlerin listesi belli olmuştur. Jandarma zaman zaman gelip köylülere baraj altında kalmamaları, evlerini taşımaları hususunda uyarılar yapmaktadır. Andırın'da geçim kaynağı bulma umutları kalmayan köylüler, en yakın yer olarak Kadirli'yi kendilerine yerleşim yeri olarak belirlemişlerdir:

“Andırın'dan kısmetimiz kesildi.

Göç listesi geldi, hemen asıldı.

Göçün diye, bir bir köyler basıldı,

Kadirli'ye doğru, bize yol oldu” (K.11).

Göç, birtakım insani değerlerin de kaybolmasına yol açmıştır:

"Artık çok azaldı hal hatır soran,

Geçmişe biz gibi yok kafa yoran,

Heybetiyle her dem ardımda duran,

Şol Dülbül Dağı'nın eteğindenim." (Hacı Musa Tuncer, Açık Adresim).

İnsanlar arasındaki dostluğun yerini küslükler almıştır:

"Ekerdik pamuğu, dikerdik fistık

Kime ne demeli, kadere küstük

Bırak komşuyu da akraba, dostuk Baraj1).

Geç kalmadan küsüşmeye başladı.” (Hacı Mehmet Dereli, Aslantaş

Göç ve hasretlik duygusu insanların canını oldukça sıkmıştır:

"Barajla yitirdim bütün anımı

Yaban ele göçtüm sıktım canımı

Hasretlik morarttı her bir yanımı

Feleğin vurduğu köteğindenim.” (Hacı Musa Tuncer, Açık Adresim).

Göç etmek zorunda kalan kişilerde çeşitli psikolojik rahatsızlıklar ortaya çıkmıştır:

"Kış günü coşardın, sellerin nerde,

Baykuşlar mı kondu şo bizim yurda?

Bütün köylülerim tutuldu derde,

Çok perişan oldu hâlın Andırın." (Abdullah Arslantaş, Andırın). 
Baraj, köylülere göre beladır ve hastalıkların da başlıca sebebidir. Hastalıklara doktorlar, ilaçlar da çare olamamaktadır:

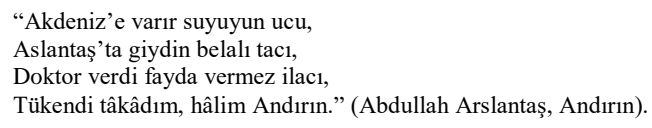

Göçmek zorunda kalanlar, yeni yerleştikleri yerde yalnızlık çekmiştir:

"Gıvrım gıvrım dağdan aşan yolları,

Mart, nisan ayında coşan selleri,

Baraj bastı çok perișan hâlları,

Garip kaldım şu ellerin içinde.” (Abdullah Arslantaş, İçinde).

Barajın topluma etkisinin yanı sıra bireye etkisi üzerinde de durulmuştur. Şiirde anlatılan Alaman Haşim'in hayatı baraj yapıldıktan sonra oldukça değişmiştir:

“Baraj bastı Düziçi'ne yerleşti,

Tüccarlık eyledi, hayat zorlaştı,

Hatır gönül menfaatte birleşti, Haşim).

Dururdu sözünde Alaman Haşim.” (Hacı Musa Tuncer, Alaman

Baraj gölünde balık tutmak için kayıklar, sandallar gezmektedir. $\mathrm{Bu}$ unsurlar zamanın geçtiğini, devrin döndügünü de göstermektedir:

"Barajda ring atar kayıkla sandal,

Kökümüz aynıdır Hasanca, Gondal,

Andırın'a Reis seçildi Hindal ${ }^{10}$, Bir Köy).

Koltuğum kabardı şol köyümüzde.” (Hacı Musa Tuncer, Anadolu'da

Artık, baraj gölü altında kalan köy arazisinin olduğu yerde balık avlanmaktadir:

"Göç etsek de ordan sanma madara

Çok şükür kimseye olmak mudara,

Aslantaş, Ilıca yeri kadara, Köy).

Tor serip oltayı ger köyümüzde.” (Hacı Musa Tuncer, Anadolu'da Bir

\footnotetext{
${ }^{10}$ Baraj gölü altında kalan Köleli köyünden olan Hindal Bozkurt, Andırın'da iki dönem belediye başkanı seçilmiştir. Bu durum, köylüleri için gurur kaynağı olmuştur.
} 
Köylüler baraj yapımının doğurduğu sonuçlara zamanla alışmak, durumu kabullenmek zorunda kalmıştır. Şiirlerde barajın faydalarından da bahsedilmeye başlanmıștır:

"Yaz günü çapaya koşardık atı,

Sira sıra idi pamuğun hat1,

Niyazi sahile dikiyor kat,,

Kumsalda baraja gir köyümüzde.” (Hacı Musa Tuncer, Anadolu'da Bir Köy).

Gurbet elde köylüler, akrabalar bir araya gelmeye başlamıştır:

"Yabancı ellere göçtük yerleştik,

Gene şükür bir yerlerde birleştik,

Köyden konu açtık, sorduk, dertleştik, Bir Köy).

Verilmez herkese sır köyümüzde." (Hacı Musa Tuncer, Anadolu'da

Yeni yerleşilen yerin ve barajın övgüsü yapılmıştır:

"Karatepe tarih, ayrı bir müze,

Aslantaş Barajı su verir düze,

Her yeri kaledir rastlanır ize,

Şahittir tarihe sır Osmaniye." (Hacı Musa Tuncer, Yiğit Osmaniye).

Barajın sağladığı faydalar art arda sıralanmıştır:

"Yeşil orman olmuş kıraç yöreler

Cennete çevrilmiş o mesireler

Amansız irmaklar, deli dereler

Sükûna kavuşmuş, baraj gölünde." (Âşık Halil Karabulut, Baraj Gölünde), (Karabulut, 1999, s. 188).

"Turist gelir, döviz çeker peşini

Bol ettiler ekmeğini aşını

Fakir fukaranın gözü yaşını

Siler iken gördüm ben bu barajı" (İ. Muzaffer Çağlayan, Aslantaş Baraj1), (Çağlayan vd. 2000, s. 221).

Kadirli şehri tanıtılırken Aslantaş Barajı da sayılır:

"İki barajı var Kesik Aslantaş

Her yanı suladı bak yavaş yavaş

Çevresi bağ bahçe seyret arkadaş

Şeftali portakal nar Kadirli'de" (Âşık Feymânî, Kadirli'de), (Âşık Feymânî, 1989, s. 45).

"Baraj yaptık kuru toprak yaşardı

Kıraç dağlar çamlık oldu yeşerdi

Yöre halkı ne yaptıysa başardı

Her yönüyle ticarete kavuştu." (Âşık Feymânî, Kadirlimiz), (Âşık Feymânî, 1989, s. 89). 
Baraja yüksek yerlerden bakıldığında güzel bir görüntüyle karşılaşılmaktadır. Ozan Duranoğlu'nun doğum yeri olan Andırın'ın Beşbucak köyü, Aslantaş Baraj Gölü’nün görülebileceği hâkim bir yerde kurulmuştur. Şiirlerine bu durum şöyle yansımıştır:

"Ceyhan nazlı akınca,

Aslantaş'a çökünce,

Yücelerden bakinca,

Poz gibi şimdi, poz gibi." (Ozan Duranoğlu, Yaz Gibi Şimdi), (Doğaner, 2019, s. 146).

"Duranoğlu geldiğinde güzleri,

Bazen ağlar bazı güler gözleri,

Yükseklerden seyrederken düzleri,

Bizim göller ne güzeldi ne güzel...

Aslantaş da ne güzeldi ne güzel..." (Ozan Duranoğlu, Ne Güzel), (Doğaner, 2019, s. 178).

Baraj, halk şiirinde bir metafor olarak da kullanılmaya başlanmıştır:

"Sabır taşım çatlar oldu,

Yeter evlat kendine gel.

Baraj bendim patlar oldu, 176).

Yeter evlat kendine gel.” (Ozan Duranoğlu, Evlat), (Doğaner, 2019, s.

Aslantaş Barajı Ağıdı (Gökahmetli köyü) ${ }^{11}$ barajla ilgili halkın düşüncelerini, barajın bölge insanı üzerindeki etkilerini göstermesi açısından önemlidir. Gökahmetli köyünden olup Bektaşlı köyünde ikamet eden, Ballı Hatın olarak bilinen Belkıs Taş (K.7) yaptığımız görüşmede şunları söylemiştir:

“Gökahmetli ünlü, şanlı bir köydü. Olmayaydı keşke bu baraj. Keşke bu barajı az daha yukarı tutsalardı. Oralarda arazi de yoktu. Berke Barajı'nın yapıldığı yerde arazi yok, köy yok. Zamanında oraya yapsalardı, bu kadar insan perişan olmazdı. Barajdan sonra biz, buraya (Bektaşlı) geldik. Tarla yok, takım yok. Elin ortakçılığına gidilmiyor, başağına gidilmiyor. Alışmamışız.

\footnotetext{
${ }^{11}$ Derlediğimiz bu ağıt, "Gökahmetli Köyü (Arslantaş Barajı)nün Ağıdı" adıyla bazı farklılıklarla Temiz'in yüksek lisans tez çalışmasında da yer almaktadır. bkz. (Temiz, 2005, s. 694, 695). Bütünlüğünü bozmamak ve örnek bir metin verebilmek amacıyla ağıdın tamamı verilmiştir.
} 
Baraj tutulmaya başlayınca Hasibe Hatın ${ }^{12}$ beni çağırmış. Oğlu Hacı ile haber yollamış. Ben söyleyeyim de Ballı bellesin, demiş. Vardım yanına önce ben söyledim:

Ballı Hatın:

Söylesene Hasib’ abla,

Baraj da geldi eline.

Düşünmene gerek yok ki

Düzülür gelir diline.

Bunun üzerine o, eli kulağa attı, başladı.

Hasibe Hatın:

Çağırın gelsin Ballı'ya,

Ben söyliyem o belliye.

Baraj bizi ayırıyo,

Yaşım da değdi elliye.

Oturdum da ben ağliyom,

Ağ gonağım bozulurkan,

Gökahmetli harab oldu,

Tarihlere yazılırkan.

Yürü bre ulu cami

Herkes sana güveniyo.

Başında ayı yıldızı

Minaremiz ciyanıyo. ${ }^{13}$

Ucdan ala Guran Kursu,

Hocalar veriyor dersi,

Hocam hutbede oturur,

Başında gırmızı fesi.

Okuryazarlığım olsa,

Galem alıp yazıcıyım.

Havas güves duttuğum gonak,

Elleheme bozucuyum.

Oturdum da ben ağlarım,

Ağ konağım bozulurken.

Gökahmetli harap oldu,

Tarihlere yazılırken.

\footnotetext{
${ }^{12}$ Hasibe Hatın, bilinen halk şairi Hasibe Hatın değildir. Ancak, bu ismi, Belkıs Taş'ın anlatımına göre bizzat Hasibe Hatın'ın kendi vermiştir: "Hasibe, Hasibe Hatın'ın kucağına doğmuştur. Kendi adını da bizim Hasibe'ye verip ağzına da bir kere tükürmüştür. İyi ki de tükürmüş ağzına. Onun kadar gözel şiirler söyledi, onun gibi hatın oldu. Tam adı da Hasibe Gök. Kocasının adı Baddal Gök. Kendi de kocası da rahmatlık oldu."

${ }^{13}$ c1yanıyo: süzülüyor.
} 
Hocalar da okur Guran, Yoğumuş arayan soran.

Tarihlere yazılırken,

Gökahmetli oldu viran.

Köylüler şehirli oldu,

Ay(1)rana hasret gald1.

Gınamasın eller bizi,

Memlekete sular doldu.

Geçmiş olsuna gelmedi,

Darısı halam gızına.

Baraj kendini de basa,

Ateşler düşe özüne.

Kimlerinen komşu ollum?

Belli olmaz elin huyu.

Geldi odalara doldu,

Olmaz olsun baraj suyu.

Ceyhan, emmimi yutdu,

Aklım da başımdan getdi,

Olmaz olasica baraj,

Bize edeceeni etdi.

\section{Ballı Hatın:}

Hasibe ablam, dediklerini bitirince bu sefer ben attım eli kulağa.

Neçe çıkdım neçe indim,

Barac gelmiyeci sandim,

Ag gonă̆ım gırmız'evim,

Babam ölük gimi yandım.

İtler içesice barac,

Ayağıma gelir gendi,

Mevlama duva ederim,

İnşallah yıkılır (delinir) bendi.

Babamoğlu Gadir Hoca,

Eviyin de yeri üce,

Olmaz olasica Barac

Halımız n'olacak nice.

Camının gözel yazısı

Taman babamın eseri,

İki gözüm gan ağlıyor,

Eller vurdukca keseri. 
Babam gızı göçmüş Çala, Ağlıyarak düşdüm yola,

Gınamasın eller bizi,

Memleket gediyor sele.

Emmimin oğlu Efendi,

Benim de ciyerim yand,,

Gadanı alayım bacı,

Babam yurdu nasıl oldu?

Geçmiş olsuna gelmedi,

Darısı halam gizına

Barac kendini de basa,

Ataşlar düşe özüne.

Gavırımış gavır barac,

Geldi odalara doldu.

Gurban olam babam gizı,

Babam yurdu nasıl oldu?"

\section{SONUÇ}

Barajlar arazi sulama, insanların su ihtiyacını karşılama, elektrik elde etme, su taşkınlarını önleme gibi birçok sebeple insanlık yararına yapılmaktadır. Aslantaş Barajı da Türkiye Cumhuriyeti devleti tarafından Çukurova'nın sulama ihtiyacını karşılamak amacıyla Ceyhan Nehri üzerine kurulmuş barajlardan ilkidir.

Barajların yapılması, bir yandan ülke ekonomisine katkı sağlarken diğer yandan özellikle arazileri su altında kalan insanların hayatını olumsuz yönde etkilemiştir. İnsanlar, yüzlerce yıldır yaşadıkları yurtlarından, geçim kaynaklarından mahrum bırakılarak gönüllü veya zorunlu göçe itilmeleri neticesinde yeni bir hayata uyum sorunuyla karşı karşıya bırakılmıştır. Bununla birlikte göç edenler, kendi kültürlerini yeni yerleşim yerlerine taşımışlar, dâhil oldukları yeni kültürden de etkilenmişlerdir.

Aslantaş Barajı'nın irili ufaklı on sekiz yerleşim yerini etkilemesi, bunlardan bazılarının arazilerinin tamamen, bazılarının da kısmen su altında kalması; bundan etkilenen insanların duygularını dışa vurmaya itmiştir. Bu dışa vurumlardan biri de ağıt yakma veya şiir yazma şeklinde kendini göstermektedir. Söz konusu edebî ürünlerde barajın daha çok olumsuz etkileriyle konu edildiği görülmektedir. Bu durumun ortaya çıkmasında eser sahiplerinin doğrudan olumsuz durumu yaşamaları ya da buna şahit olmaları etkili olmuştur.

Barajdan olumsuz manada etkilenmeyen halk şairleri eserlerinde konuya olumlu yönleriyle değinmişler, barajın sağladığ 1 faydalardan, 
oluşturduğu doğal güzellikten bahsetmişlerdir. Halk şiiri örneklerinden yola çıkarak insanların zamanla barajı kabullenmek zorunda kaldığ görülmektedir.

Gerek bölgesel gerekse küresel ölçekteki toplumu ilgilendiren olaylar halk edebiyatı ürünlerine, özellikle de halk şiirine gecikmeden yansımaktadır. Sözlü kültür tarihi çalışmaları açısından halkın olaylara tepkisini, halkta oluşan duygu ve düşünceleri gösteren edebî ürünler büyük önem taşımakta, araştırmacılara önemli veriler sunmaktadır.

\section{KAYNAKÇA}

Alptekin, A. B. (2011). Baraj suları altında kalan somut olmayan kültürel miras. Halk bilimi araştırmaları içinde 307-315, Ankara: Akçağ.

Anık, F. (1997). Barajlar ve çevre. Türkiye Mühendislik Haberleri, 392, 27-34.

Aslantaş, H. (2015). Aslantaş barajı neleri yuttu. İstanbul: Cinius.

Âşık Feymânî (1989). Ahu gözlüm. Ankara: Kültür Bakanlığı.

Âşık Feymânî (2015). Zamanı geldi (S. M. Taşkaya, Haz.). Kadirli Kaymakamlığı.

Çağlar, A. (2002). Barajların sosyal etkileri: Ceyhan-Aslantaş barajı örneği. Sosyoloji Araştırmaları Dergisi, 2, 47-103.

Çağlayan, A. ve Çağlayan, M. (2000). Kadirli'de Çağlayanlar $l l$. Kadirli Hizmet Birliği.

Doğaner, A. (2013). Çukurova bölgesi konar-göçerlerinde halk kültürü ve halk edebiyatı. Yayımlanmamış doktora tezi, Çukurova Üniversitesi Sosyal Bilimler Enstitüsü, Adana.

Doğaner, A. (2019). Ozan Duranoğlu (hayatı-sanatı-şiirleri). Adana: Karahan.

Ersoy, R. (2003). Yerelden evrensele maddi kültür unsurları ve kooperatifçilik Osmaniye Karatepe Kızyusuflu köy kooperatifi örneği. İstanbul Üniversitesi, Motif Halk Oyunları Eğitim Derneği, Gençlik ve Spor Kulübü, İstanbul, 12-14 Aralık 2003 $<$ http://turkoloji.cu.edu.tr/HALKBILIM/ruhi_ersoy_kooperatif.pd f Erişim tarihi: 07.01.2021>.

Evren, B. (2012). Apo gardaş Abdurrahman Keskiner. Adana: Altın Koza. 
İşlek, B. (2010). Bir cerene av olmak. İstanbul: Çatı.

Karabulut, H. (1999). Şiire adanan ömür. Kadirli Hizmet Birliği.

Koca, N. (2017). Doğal ve sosyo-ekonomik özellikleri açısından Osmaniye yaylalart. Ankara: Pagem.

Öner, İ. (2001). Barajların yaşam seyri sürecinde yapılan sosyal çalışmalara, muhtemel afetlere hazırlık açısından bir bakış. Sosyoloji Araştırmaları Dergisi, 8 (1-2), 1-34.

Yeni resimli bilgi ansiklopedisi 7 (1983). İstanbul: Baskan.

Temiz, M. (2005). Andırın ă̆ıtları. Yayımlanmamış yüksek lisans tezi, Furat Üniversitesi Sosyal Bilimler Enstitüsü, Elazığ. 


\section{SÖZLÜ KAYNAKLAR}

K.1: Abdullah Arslantaş, 1953-Andırın doğumlu, ortaokul mezunu, emekli işçi ile 19.05.2020 tarihinde Osmaniye'de yapılan görüşme.

K.2: Namık Gök, 1961-Andırın doğumlu, yüksekokul mezunu, emekli sağlık memuru ile 26 Eylül 2020 tarihinde Yeşilova kasabasında yapılan görüşme.

K.3: Adil Gök, 1940-Andırın doğumlu, ilkokul mezunu, emekli ile 26 Eylül 2020 tarihinde Gökahmetli köyünde yapılan görüşme.

K.4: Dursun Özdemir (Variyanlı Dursun), 1939-Andırın doğumlu, okuryazar, emekli ile 5 Ekim 2020 tarihinde Erenler köyünde yapılan görüşme.

K.5: Mustafa Erdem, 1966-Kadirli doğumlu, lise mezunu, fotoğrafçı ile 5 Eylül 2020 tarihinde Düziçi'nde yapılan görüşme.

K.6: Sariye Gök, 1946-Andırın doğumlu, okuryazar, ev hanımı ile 26 Eylül 2020 tarihinde Gökahmetli köyünde yapılan görüşme.

K.7: Belkıs Taş, 1945-Andırın doğumlu, ilkokul mezunu, ev hanımı ile 26 Eylül 2020 tarihinde Bektaşlı köyünde yapılan görüşme.

K.8: Hacı Musa Tuncer, 1964-Andırın doğumlu, yüksekokul mezunu, emekli polis memuru ile 25 Eylül 2020 tarihinde Adana'da yapılan görüşme.

K.9: Ebubekir Aslantaş, 1950-Andırın doğumlu, ilkokul mezunu, emekli ile 29.12.2020 tarihinde yapılan telefon görüşmesi.

K.10: Seyfullah Türkmenoğlu, 1962-Kadirli doğumlu, yüksekokul mezunu, emekli ile 02.01.2021 tarihinde yapılan telefon görüşmesi.

K.11: Mehmet Keskin, 1967-Haruniye doğumlu, okuryazar, şoför ile 05.01.2021 tarihinde yapılan telefon görüşmesi.

K.12: Mahmut Eynallı, 1956-Beşbucak köyü doğumlu, üniversite mezunu emekli öğretmenle 07.01.2021 tarihinde yapılan görüşme.

K.13: Süleyman Türkmenoğlu, 1967-Kızyusuflu köyü doğumlu, üniversite mezunu öğretmenle 02.01.2021 tarihinde yapılan telefon görüşmesi. 


\section{ETİK KURUL ONAYI}

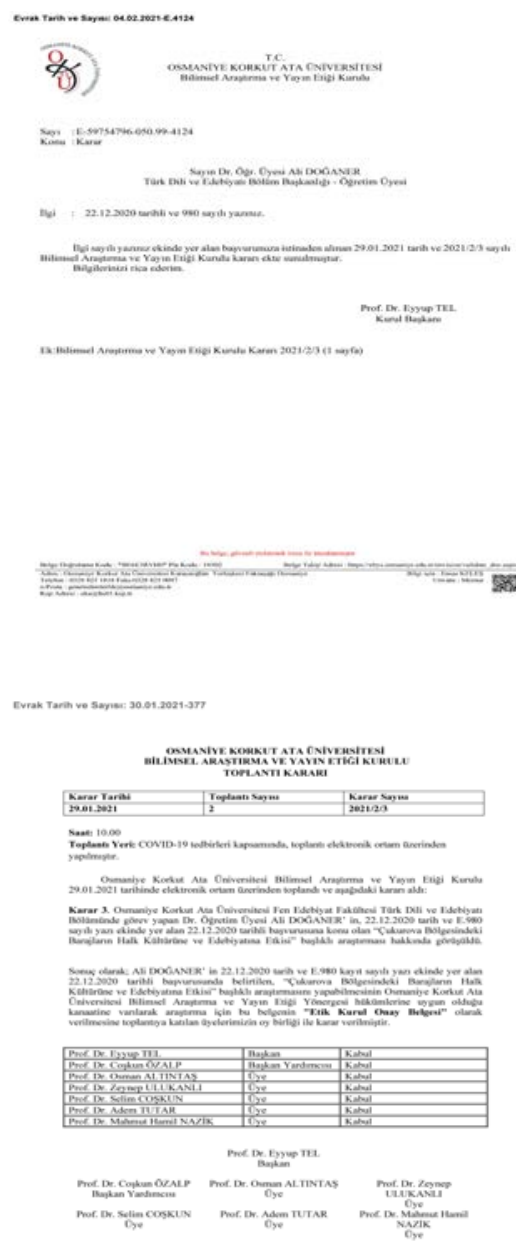

